\title{
Advantages of bedside ultrasound in the emergency department
}

\author{
Adeel Akhtar, ${ }^{1}$ Shah Sarmad ${ }^{2}$ Emma Greenwood ${ }^{2}$
}

'Department of Emergency Medicine, Belfast Trust, Belfast, UK

${ }^{2}$ Department of Emergency Medicine, Belfast Trust, Belfast, UK

\section{Correspondence to}

Dr Adeel Akhtar, adeelakhtar@doctors.org.uk

\section{DESCRIPTION}

An 18-year-old girl presented to the emergency department with a 2-day history of right iliac fossa pain and vomiting. She reported difficulty in passing urine for $24 \mathrm{~h}$. Her medical history included hypothyroidism.

On abdominal examination, the patient was found to be tender in the right iliac fossa with a palpable bladder. The patient was unable to provide a urine sample and was subsequently catheterised with $50 \mathrm{ml}$ residual urine. Urinalysis demonstrated ketones $80 \mathrm{mg} / \mathrm{dl}$, protein $30 \mathrm{mg} / \mathrm{dl}$ and a trace of blood. Urine $\beta$-human chorionic gonadotropin hormone was negative.

A decision was made to re-catheterise the patient with ultrasound being performed during catheterisation. A catheter tip was identified within the empty bladder, and a large fluid-filled cyst was noted to compress the bladder (figure 1). A provisional diagnosis of a large ovarian mass was made, and the patient was transferred to the gynaecology team for further management. A CT scan of the abdomen and pelvis was performed which demonstrated a large ovoid haemorrhagic ovarian cyst measuring $13 \times 9 \times 16 \mathrm{~cm}$ (figure 2). Subsequently, the patient had laparotomy and right oophorectomy. Although the CT scan had queried adenoma or carcinoma, the histopathology report did not show any evidence of malignancy.

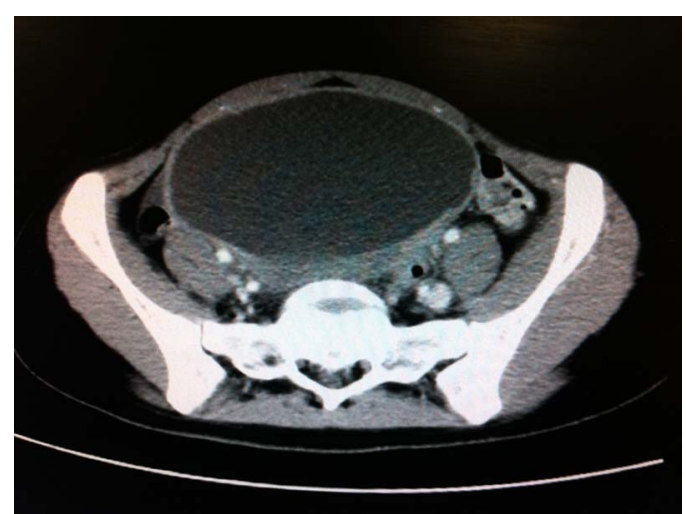

Figure 2 CT scan demonstrating a large ovarian cyst.

Learning point

- Ultrasound is the gold standard for diagnosis of ovarian cysts. ${ }^{1}$ This case demonstrates that the appropriate use of simple bedside ultrasound in the emergency department can aid a patient's diagnosis and appropriate management.

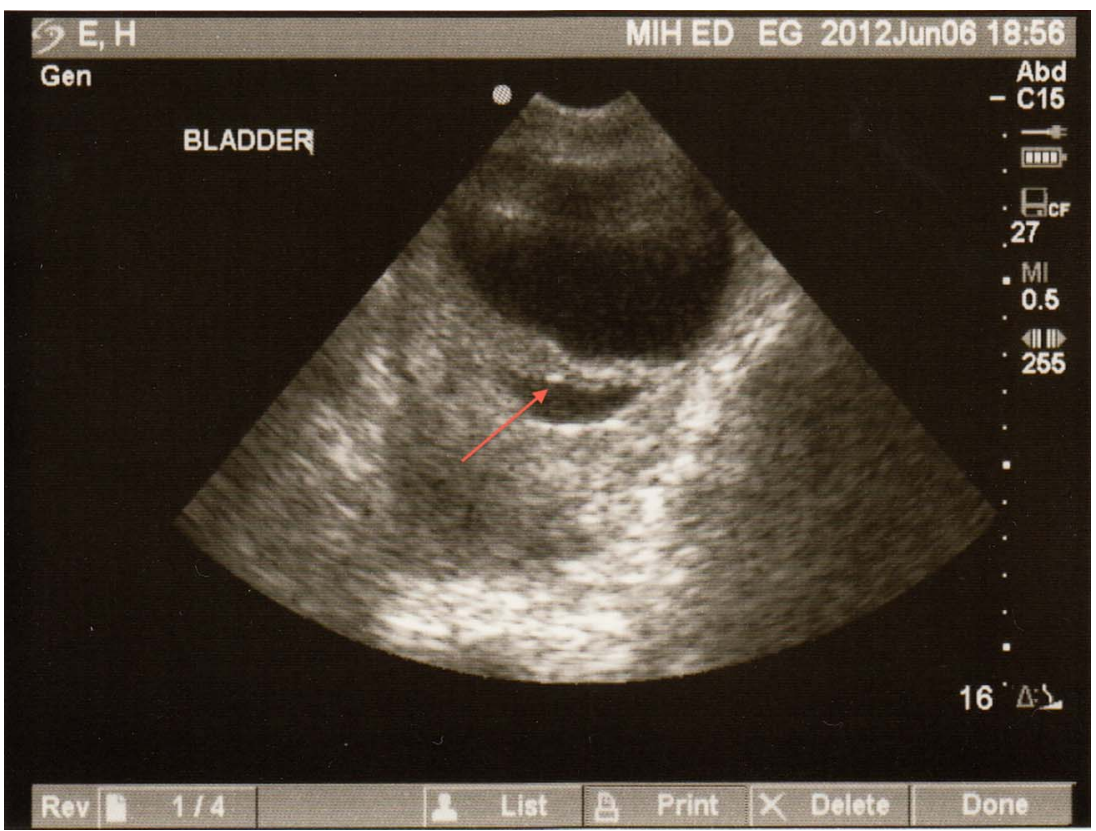

To cite: Akhtar A 
Competing interests None.

Patient consent Obtained.

Provenance and peer review Not commissioned; externally peer reviewed.

\section{REFERENCE}

1 Cartault A, Caula-Legriel S, Baunin C, et al. Ovarian masses in adolescent girls. Endocr Dev 2012;22:194-207.

Copyright 2013 BMJ Publishing Group. All rights reserved. For permission to reuse any of this content visit http://group.bmj.com/group/rights-licensing/permissions.

BMJ Case Report Fellows may re-use this article for personal use and teaching without any further permission.

Become a Fellow of BMJ Case Reports today and you can:

- Submit as many cases as you like

- Enjoy fast sympathetic peer review and rapid publication of accepted articles

- Access all the published articles

- Re-use any of the published material for personal use and teaching without further permission

For information on Institutional Fellowships contact consortiasales@bmjgroup.com

Visit casereports.bmj.com for more articles like this and to become a Fellow 